\title{
Mass propagation of Dendrocalamus asper through tissue culture and comparison of selected morphological, physical and anatomical features with seed raised plants
}

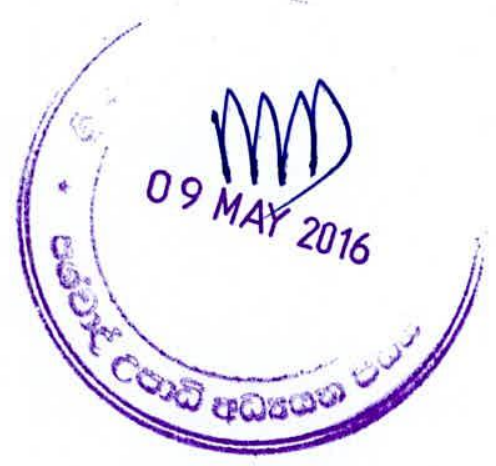

by

KUMBURE GEDARA PRIYANTHA HEMALAL CHANDRASENA

Thesis submitted to the University of Sri Jayewardenepura for the award of the Degree of Doctor of Philosophy in Botany on $31^{\text {st }}$ January 2016. 


\section{DECLARATION BY THE CANDIDATE}

The work described in this thesis was carried out by me under the supervision of Prof. (Mrs.) W.T.P.S.K. Senarath (Department of Botany, University of Sri Jayewardenepura) and Prof. Hiran Amarasekara (Department of Forestry and Environmental Sciences, University of Sri Jayewardenepura) and a report on this has not been submitted in whole or in part to any university for any other degree/Diploma.

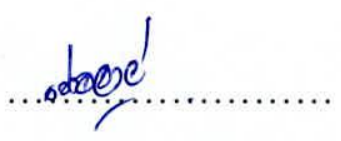

$09.05: 2016$

K.G.P.H. Chandrasena

Date

B.Sc. (Biology), M.Phil. (Botany) 


\section{CERTIFICATION OF SUPERVISORS}

We certify that the candidate has incorporated all corrections, additions and amendments recommended by the examiners.

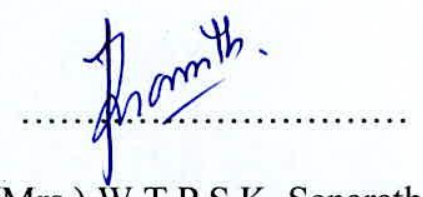

Prof. (Mrs.) W.T.P.S.K. Senarath

Head of the Department,

Department of Botany,

University of Sri Jayewardenepura,

Gangodawila, Nugegoda, Sri Lanka.

Date: $0.5 / 05 / 16 \ldots . . .$.

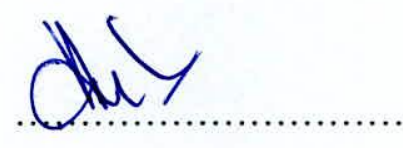

Prof. Hiran Amarasekara

Professor,

Department of Forestry and

Environmental Sciences,

University of Sri Jayewardenepura,

Gangodawila, Nugegoda, Sri Lanka.

Date: $5|5| 2016$ 


\section{TO}

sasan putha,

Harithashi duwa,

छ

Amma

Who sacrifice more than me

Towards this effort.

Together we made it... 


\section{TABLE OF CONTENTS}

Content

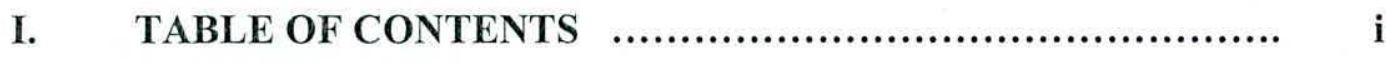

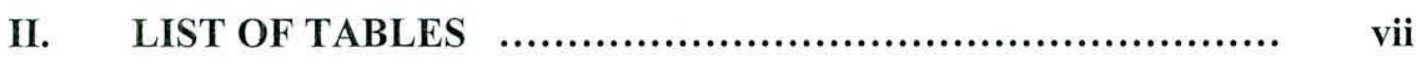

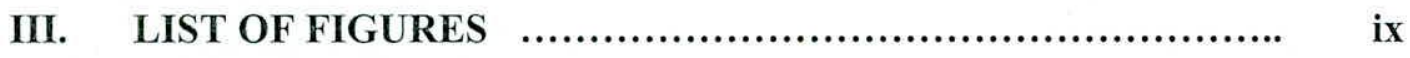

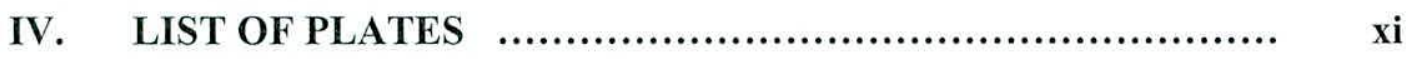

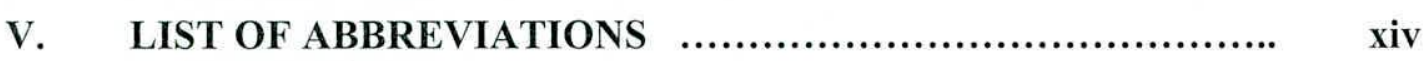

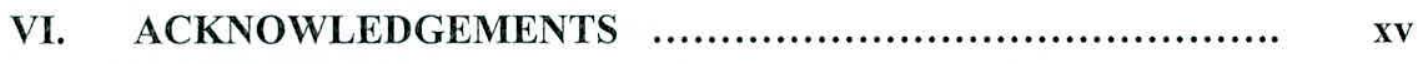

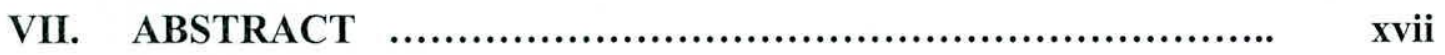

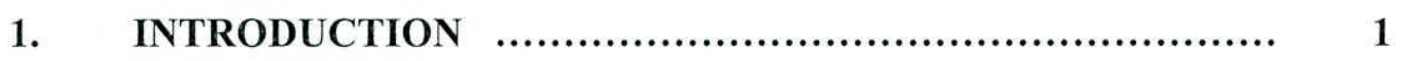

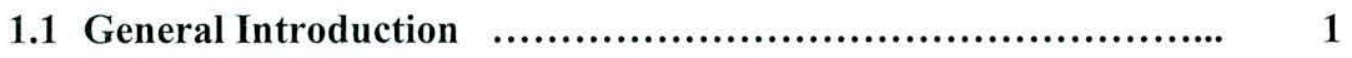

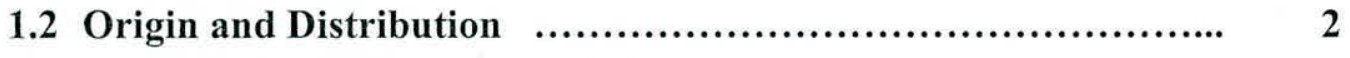

1.3 Economic Importance of Dendrocalamus asper $\ldots \ldots \ldots \ldots \ldots \ldots . . . \ldots$

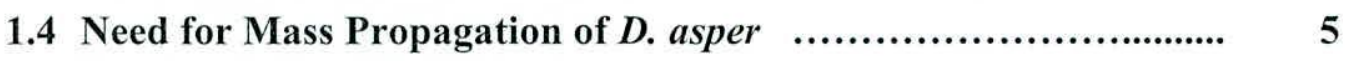

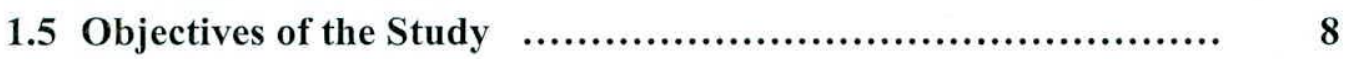

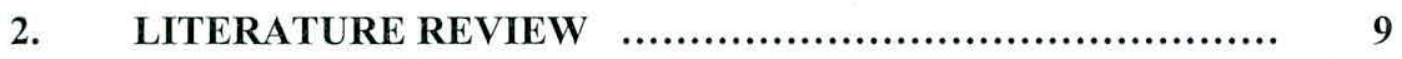

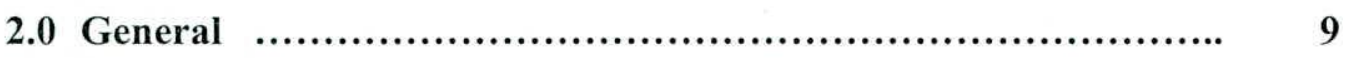

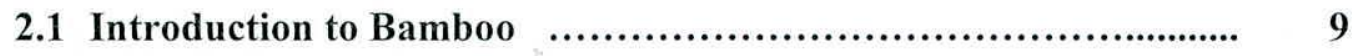

2.2 Global and Sri Lankan Context of Bamboo $\ldots \ldots \ldots \ldots \ldots \ldots \ldots \ldots \ldots . . \ldots$

2.3 Distribution of $D$. asper in Sri Lanka and Globally $\ldots \ldots \ldots \ldots \ldots \ldots . . . . .11$

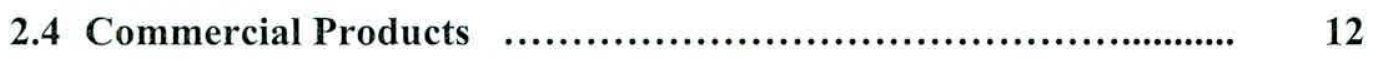




\subsection{Taxonomy, Morphology, Growth and Anatomical Structure}

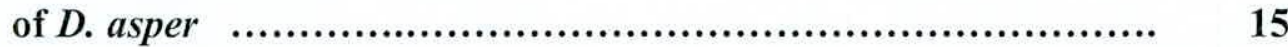

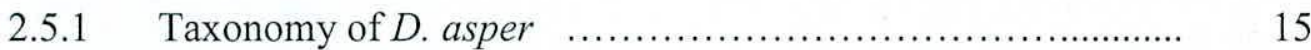

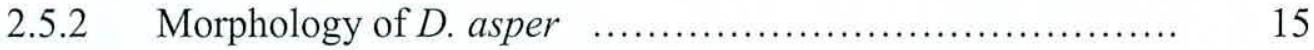

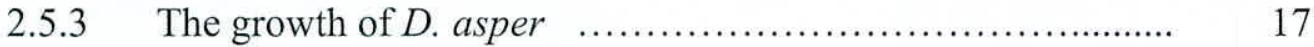

2.5.4. Anatomical structure of $D$. asper $\quad$............................. 19

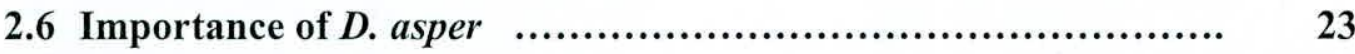

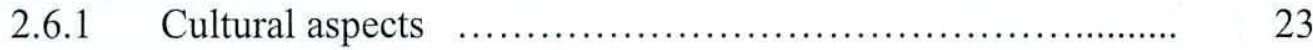

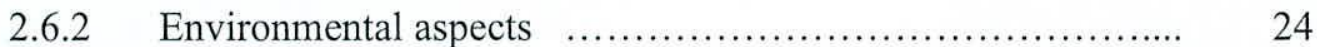

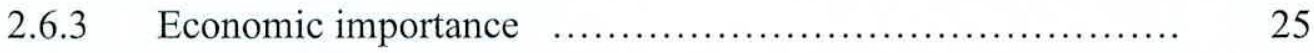

2.6.4 Nutritional and nutraceutical value of D. asper ............. 27

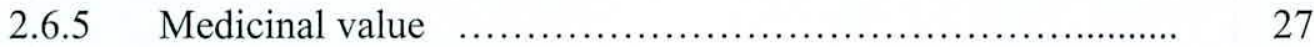

2.7 Plant Tissue Culture Technology $\ldots \ldots \ldots \ldots \ldots \ldots \ldots \ldots \ldots \ldots \ldots . \ldots \ldots$

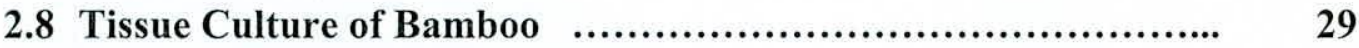

2.8.1 Use of axillary buds of bamboo for micropropagtion $\ldots . . . . \quad 30$

2.8.2 In vitro germination of seeds and embryos $\ldots \ldots \ldots \ldots \ldots \ldots . . \ldots \ldots$

2.8.3 Tissue culture of Genus Dendrocalamus $\quad$..................... 32

2.8.4 Tissue culture of Dendrocalamus asper ................... 37

2.8.5 Field establishment of micropropagated bamboo and comparison with conventionally grown plants $\ldots \ldots \ldots \ldots \ldots \ldots . . \ldots . .41$

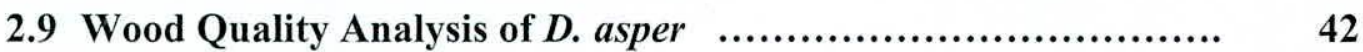

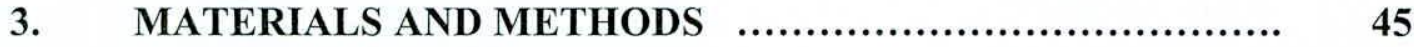

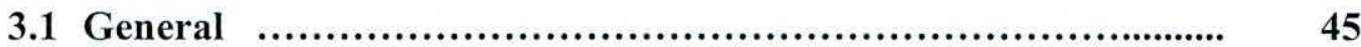


3.2 Determination of Suitable Starting Material for $D$. asper Mass

Propagation $\quad$........................................................ 47

3.2.1 Determination of percentage in vitro seed germination $\ldots . . . \quad 47$

3.2.2 Use of nodal segments from secondary branches of mature plants as a starting material

3.2.3 Determination of the best growth regulator combination for in vitro shoot initiation from nodal segments obtained from in vitro raised seedlings and vegetatively propagated plants

3.3 Determination of the Best Medium for Shoot Multiplication and Elongation

3.4 Effect of Shoot Cluster/Propagual Size on Shoot Multiplication .

3.5 Determination of Suitable State of the Medium (Liquid or Semi-solid) for Shoot Multiplication and Elongation

3.6 Determination of Best Growth Regulator Concentration for

Induction of Roots

3.7 Effect of Shoot Cluster/Propagule Size on Root Initiations $\ldots . . . . \quad 50$

3.8 Acclimatization of Micropropagated Plantlets of $D$. asper ........... 51

3.9 Comparison of the Growth of in vitro Propagated and Seed Raised Plants of $D$. asper

3.9.1 Comparison of shoot morphology of tissue cultured plants and seed raised plants grown in the field

3.9.2 Comparision of the chlorophyll a, b and total chlorophyll content in seed raised and tissue cultured plants of $D$. asper 
3.10Determination of the Most Suitable Geographical Area in Sri Lanka

to Establish D. asper as Commercial Plantations $\ldots \ldots \ldots \ldots \ldots \ldots . . . \ldots 5$

3.11Comparison of Basic Morphological, Physical and Anatomical

Properties of Mature Plants of Seed Raised and Micropropagated

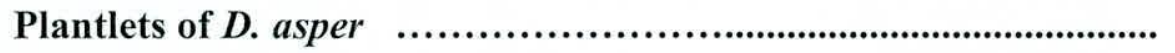

3.11.1 Comparison of basic morphological properties of mature plants of micropropagated and seed raised plants of D. asper ....... 57

3.11.2 Comparison of specific gravity values as a physical property of tissue cultured and seed raised plants of $D$. asper $\quad \ldots \ldots \ldots . . . \quad 58$

3.11.3 Comparison of anatomical properties of tissue cultured

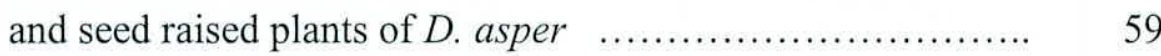

3.12 Number of Plants/Explant and Cost per Plant $\ldots \ldots \ldots \ldots \ldots \ldots \ldots .61$

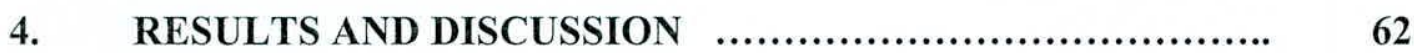

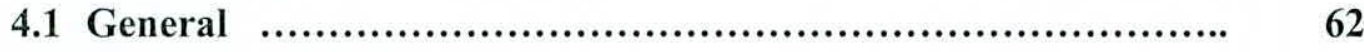

4.2 Determination of Suitable Starting Material for $D$. asper

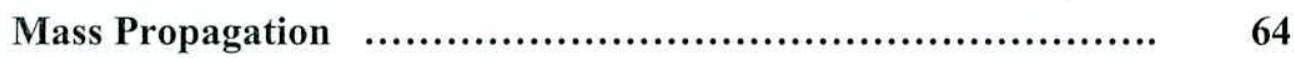

4.2.1 Determination of percentage in vitro seed germination $\ldots . . . \quad 64$

4.2.2 Use of nodal segments from secondary branches of mature plants as a starting material

4.2.3 Determination of best growth regulator combination for in vitro shoot initiation from nodal segments obtained from in vitro raised seedlings and vegetatively propagated plants 


\subsection{Determination of the Best Medium for Shoot Multiplication}

and Elongation

4.4 Effect of Shoot Cluster/Propagule Size on Shoot Multiplication .

4.5 Determination of Suitable State of the Medium (Liquid or Semi-Solid) for Shoot Multiplication and Elongation

4.6 Determination of Best Growth Regulator Concentration for

Induction of Roots

4.7 Effect of Shoot Cluster/Propagule Size on Root Initiation ......... 83

4.8 Acclimatization of Micropropagated Plantlets of $D$. Asper ........ 85

4.9 Comparison of the Growth of in vitro Propagated and Seed

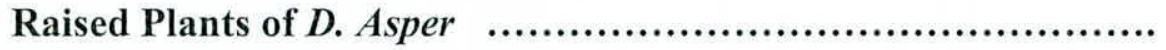

4.9.1 Comparison of shoot morphology of tissue cultured plants and seed raised plants grown in the field

4.9.2 Comparision of chlorophyll a, b and total chlorophyll content in seed raised and tissue cultured plants of $D$. asper

4.10 Determination of Most Suitable Geographical Area in Sri Lanka to Establish D. Asper as Commercial Plantations

4.11 Comparison of Basic Morphological, Physical and Anatomical Properties of Mature Plants of Seed Raised and Micropropagated Plants of D. Asper

4.11.1 Comparison of morphological properties of mature plants of micropropagated and seed raised plants of D. asper

4.11.2 Comparison of specific gravity of tissue cultured and seed raised mature plants of $D$. asper 
4.11.3 Comparison of anatomical properties of tissue cultured and seed raised mature plants of $D$. asper

5. CONCLUSIONS AND RECOMMENDATIONS

5.1 Conclusions

6. REFERENCES 


\section{LIST OF TABLES}

Table

Page No.

Table $3.1 \quad$ Different potting mixtures tested for the growth of micropropagated plantlets of D. asper

Table 4.1 In vitro seed germination percentage of $D$. asper after 21 days of incubation in GR free MS media 64

Table 4.2 Mean no of shoots, mean lengths and no. of leaves obtained after six weeks of incubation in media supplemented with different BA concentrations 71

Table 4.3 Growth of shoot clusters as a response to different concentrations of BA after eight weeks 74

Table 4.4 Effect of initial shoot cluster size on root initiation of in vitro raised shoots of $D$. asper after 8 weeks of incubation 83

Table $4.5 \quad$ Basic morphological parameters of $4 \frac{1}{2}$ years old micropropagated plants and seed raised plants after $4 \frac{1}{2}$ years of establishment in the field 102

Table 4.6 Comparision of findings of macroscopic charasteristics of D. asper with previous reports on D. asper

Table 4.7 Specific gravity values of mature plants of tissue cultured and seed raised $D$. asper. Mean SG value for the plant and variation of SG value along the culm

Table 4.8 Percentage area covered by the vascular bundles of tissue cultured and seed raised plants 
Table 4.9 Variation of diameter of meta xylem vessels and Phloem sieve tube elements along the culm and between two plant types of D. asper 


\section{LIST OF FIGURES}

Figure

Page No.

Figure 3.1 Planting pattern of seedlings and tissue cultured plants in the experimental field site

Figure 3.2 Sampling procedure for each culm and procedure for sample preparation for the measurement of specific gravity and anatomical studies

Figure 4.1 Shoot number, shoot length and no. of leaves derived from nodal segments in response to different concentrations of BA

Figure 4.2 Mean shoot no. increment, mean shoot length increment and mean no. of leaves produced with different concentrations of BA in the multiplication and elongation stage

Figure 4.3 Effect of propagule/shoot cluster size on shoot multiplication and vigour of shoots produced after six weeks of incubation in MS medium supplemented with $2.0 \mathrm{mg} / \mathrm{L} \mathrm{BA}$

Figure 4.4 Effect of liquid and agar solidified medium on shoot multiplication and elongation in MS medium supplemented with $2.0 \mathrm{mg} / \mathrm{L} \mathrm{BA}$ after 6 weeks

Figure 4.5 Mean root number and mean root lengths achieved at the root initiation stage for different concentrations of IBA and IAA .

Figure 4.6 Increment of mean shoot number, mean shoot length and leaf number of 1 year old seed raised and tissue cultured plants of D. asper 
Figure 4.7 Variation in total chlorophyll content with the time in tissue cultured and seed raised plants of D. asper

Figure 4.8 Variation of chlorophyll a content with the time in tissue

cultured and seed raised plants of D. asper

Figure 4.9 Variation of chlorophyll $\mathrm{b}$ content with the time in tissue cultured and seed raised plants of $D$. asper

Figure 4.10 Mean number of culms/bush, mean culm height and mean number of leaves per culm after one year of establishment of tissue cultured D. asper in different localities 95

Figure 4.11 Basic morphological parameters of micropropagated plants and seed raised plants after $4 \frac{1}{2}$ years of establishment in the field

Figure 4.12 Variation of internode length along the height from base to apex of tissue cultured and seed raised plants

Figure 4.13 Variation of percentage of area covered by vascular bundles along the culms of tissue cultured and seed raised plants

Figure 4.14 Variation of diameter of phloem sieve tube elements and meta xylem cell along the culms of tissue cultured plants and seed raised plants of $D$. asper 


\section{LIST OF PLATES}

Plate

Page No.

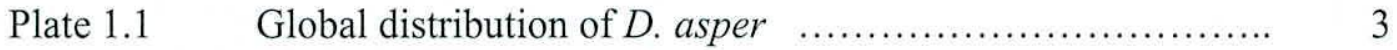

Plate 2.1 Culm morphology of $D$. asper $\quad \ldots \ldots \ldots \ldots \ldots \ldots \ldots \ldots \ldots \ldots \ldots \ldots \ldots \ldots \ldots$

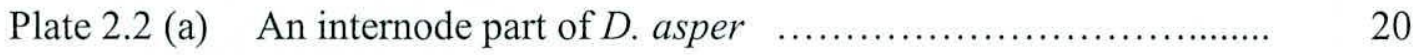

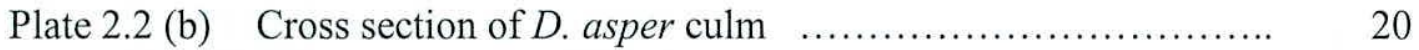

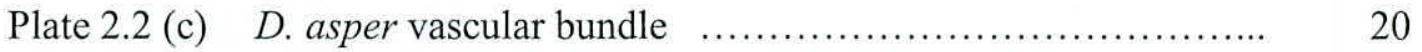

Plate 2.3 Microstructure of D. asper for (a) culm circular cross Section, (b) distribution of vascular bundles from the outer to the inner surface and (c) parenchyma cells and vascular bundle which

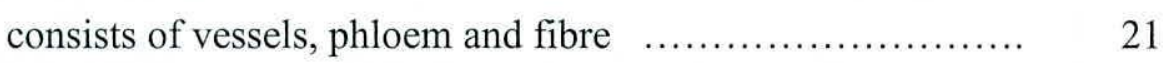

Plate 3.1 Twelve field establishment sites of tissue cultured D. asper

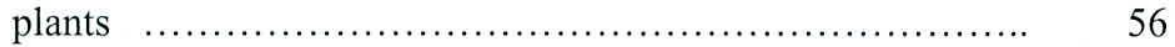

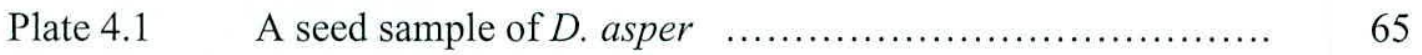

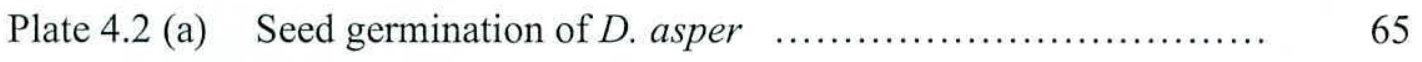

Plate 4.2 (b) 8 weeks old seedling used to take nodal segments ............ 65

Plate 4.3 Single nodal segment cultures of field grown D. asper ......... 67

Plate 4.4 Shoot initiation from nodal segments taken from in vitro germinated seedlings. (a) Two weeks after incubation (b) 4 weeks after incubation

Plate 4.5 Multiple shoot initiation from nodal segments taken from seedlings after 6 weeks of incubation as a response to GR (BA) treatments. (a) MS medium with $1.0 \mathrm{mg} / \mathrm{L} \mathrm{BA}$ and (b) MS medium $1.5 \mathrm{mg} / \mathrm{L} \mathrm{BA}$ 
Plate $4.6 \quad$ (a) Shoot multiplication and elongation under in vitro conditions (b) and (c) Sub culture stages in multiplication

(d) Shoot clusters ready to transfer root initiation media

Plate 4.7 Shoot multiplication based on initial shoot cluster size (a)

with 2 shoots per propagule and (b) with 3 shoots per propagule

Plate $4.8 \quad$ (a) Shoot multiplication and elongation on liquid and

(b) Agarified media

Plate 4.9 (a) Root initiation cultures under the growth room condition $\ldots$

Plate 4.9 (b) A rooted shoot cluster of in vitro raised plantlet of $D$. asper .

Plate 4.10 Variation of root formation with initial shoot cluster size ....

Plate 4.11 Growth of micropropagated D. asper during acclimatization

(a) in vitro raised plants placed in $50 \mathrm{~mm}^{3}$ coir pellets (b)

potted plantlets maintained for a month in humid chambers

(c) plantlets maintained in pellets under nursery condition

after removing the humid chamber and (d) plantlets

transferred to 1:1:1 (Compost: sand: coir dust) and

maintained for one month under nursery conditions

Plate 4.12 Field establishment of tissue cultured and seed raised plants of

D. asper (a) in the field at the initial stage (b) after one year

of establishment at the university botanical garden

Plate 4.13 Micropropagated D. asper plants growing at different field establishment sites 
Plate 4.15 Preparation of specimens for measuring specific gravity values of D. asper

Plate 4.16 Measuring diameter of mataxylem vessel and phloem sieve tube in a vascular bundle of cross section of D. asper culm ..

Plate 4.17 Anatomical features of $D$. asper plants(a) culm cross section (top part) of the tissue cultured plants (b) culm cross section (top part) of the seed raised plants (c) culm cross section (middle part) of the tissue cultured plants (d) culm cross section (middle part) of the seed raised plants (e) culm cross section (bottom part) of the tissue cultured plants (f) culm cross section (bottom part) of the seed raised plants 


\section{LIST OF ABBREVIATIONS}

\begin{tabular}{|c|c|}
\hline BAP; BA & 6-benzylaminopurine \\
\hline $\mathrm{DBH}$ & Diameter at breast height \\
\hline FYM & Farm Yard Manure \\
\hline $\mathrm{GA}_{3}$ & Gibberellic acid \\
\hline IBA & Indole-3-butyric acid \\
\hline IAA & Indole-3-acetic acid \\
\hline Kin & Kinetin \\
\hline OSB & Oriented Strand Board \\
\hline OSL & Oriented Strand Lumber \\
\hline MS & Murashige and Skoog`s (1962) medium \\
\hline MSL & Mean Sea Level \\
\hline NAA & $\alpha$-naphthaleneacetic acid \\
\hline TDZ & Thidiazuron \\
\hline $2,4-\mathrm{D}$ & 2,4-dichlorophenoxyacetic acid \\
\hline
\end{tabular}




\section{ACKNOWLEDGMENT}

I would like to express my sincere appreciation to all who has been involved in completion of my theses. First of all I wish to express my sincere gratitude to my supervisors Prof. (Mrs.) W.T.P.S.K. Senarath, Head of the Department, Department of Botany, Faculty of Applied Sciences, University of Sri Jayewardenepura and Prof. Hiran Amarasekara, Former Head of the Department, Professor, Department of Forestry and Environmental Sciences, Faculty of Applied Sciences, University of Sri Jayewardenepura, for their relentless guidance, continuous monitoring, supervision and critical comments and constant encouragement for the completion of the theses.

My sincere gratitude is also extended to my previous and present working places throughout the course of this study, Touchwood Investments PLC who initially financed for the USJP-TOUCHWOOD Biotechnology Research Project. Coordinating Secretariat for Science Technology and Innovation Sri Lanka (COSTI) where I had the opportunity to get good exposure to scientific community and literature for my research. Borneo Exotics pvt. LTD, for offering me a career opportunity at a time of need.

I wish to express my regards to everyone in all field establishment sites, without their assistance this work would be an uphill task.

I must thankfully remember Mr. Antonios Levissianos, Senior Industrial Development Officer and Dr. Victor Brias, Chief Technical Advisor of United Nations Industrial Development Organization for their encouragement to complete my studies. 
I wish to thank non-academic staffs of Faculty of Graduate Studies, Department of Chemistry, Department of Zoology, Department of Forestry and Environmental Sciences and everyone at the Department of Botany specially Mr. Wijesinghe and Mr. R. Kandambi, Senior Technical Officers for their assistance.

My thanks also extended to Mr. Udara Dissanayake and Miss. Samangi Hewage for assisting in statistical analysis and for technical support.

I also wish to thank Miss. R. Samarawickrama, Senior Assistant Librarian, University of Sri Jayewardenepura, Miss K. Peeris and Miss. V. Rajapakse, Education Assistants of Open University of Sri Lanka for providing me valuable references for this work. I also grateful to Jiffy Products, Sri Lanka and Techno-Aircon for their valuable support and material supply to complete this work.

My deep appreciations go out to my friends at the tissue culture laboratory Mr. Arosha Buddhapriya, Mr. Sanjika Herath, Mr. C. Somarathne, Miss. Thejani, Miss. Anuththara Abeywickrama, who helped me in numerous ways.

Last but not least my heartiest thank goes to my two kids Sasan and Harithashi who lost their fatherly care many times and my wife for understanding and bearing every difficulty at home and my father who single handedly raised six of us for long thirty years and still wishing the best things to happen on our way. 


\title{
Mass propagation of Dendrocalamus asper through tissue culture and comparison of selected morphological, physical and anatomical features with seed raised plants
}

\section{Priyantha Hemalal Chandrasena}

\begin{abstract}
Dendrocalamus asper is an introduced bamboo species adapted well into intermediate climatic conditions in Sri Lanka which has many uses of high economic and environmental importance. The objective of the present study was to develop a protocol for in vitro mass propagation, selecting suitable areas to grow the plant in the country and to investigate some of the macroscopic and microscopic properties of the micropropagated plants grown in the field to recommend suitability of the species as an alternative for growing demand of wood and wood based products.
\end{abstract}

Suitability of nodal segments from secondary branches of nursery maintained plants as explants were experimented as it is the most commonly available material, however higher level of microbial contaminations were observed. Therefore nodal segments from in vitro germinated seedlings were used. Maximum seed germination percentage achieved was $23.7 \%$. MS with $1.0 \mathrm{mg} / \mathrm{L} \mathrm{BA}$ was the best medium for shoot induction with high number of shoots $(16.87 \pm 0.52)$, higher shoot length $(4.12 \pm 0.27 \mathrm{~cm})$ and with a mean of $4.80 \pm 0.33$ leaves after 6 weeks of incubation. MS medium supplemented with $2.0 \mathrm{mg} / \mathrm{L}$ BA produced a mean number of $11.73 \pm 1.59$ of shoots with $9.21 \pm 0.55 \mathrm{~cm}$ mean shoot length and $12.2 \pm 1.21$ of mean leaf number after 6 weeks of incubation. It was observed that the shoot multiplication varies with the number of shoots in a cluster and three shoots per cluster produced higher number of elongated shoots with higher 
number of leaves. Liquid medium was found to be more suitable than solidified medium for multiplication. It was observed that $100 \%$ rooting could be obtained in the $1 / 2 \mathrm{MS}$ medium supplemented with $2.0 \mathrm{mg} / \mathrm{L}$ IBA after 6 weeks of incubation. Acclimatization could be achieved by transferring tissue cultured plantlets to $50 \mathrm{~mm}^{3}$ coir pellets and maintaining them in the humid chamber for one month and gradually exposing to $70 \%$ shade in the following month. Then, plantlets were transferred to potting mixture consisted of sand:compost:coir dust (1:1:1) and obtained 100\% survival rate.

The growth pattern of tissue cultured plants in the field was compared with seed raised plants after one year of establishment in the field. Tissue cultured plants showed better growth in the field with significantly higher mean number of shoots, mean shoot length and the mean leaf number than seed raised plants. The increase in chlorophyll contents of both plant types was observed with time and slightly higher values observed in tissue cultured plants. In order to find suitable climatic area for the establishment of large scale plantations of $D$. asper in Sri Lanka, tissue cultured plants were established in twelve sites in different Geo-climatic zones. After one year of growth, they established well and showed healthy growth in all tested sites, however, significant differences in growth were observed at different sites. Gannoruwa area was found as the best for the growth of $D$. asper. Drier areas such as Jaffna and Hambantota also indicated that, plants could be well established, but showed low performances compare to the other sites. Some of the macroscopic and microscopic characteristics of four and half years old matured tissue cultured plants were compared with similar aged seed raised plants and indicated tissue cultured plants have similar or better qualities which proves the suitability of the end product for its wide array of commercially valuable uses. The protocol developed was able to reduce the cost of a plant to LKR 4.50. 